\title{
The Role of Intellectual Capital, Intrinsic Motivation, and Competence on Service Performance: Empirical Studies at Jakarta Private Universities
}

\author{
Suryono Efendi ${ }^{1}$, Edy Rahardja ${ }^{2}$ \\ ${ }^{1}$ Universitas Nasional Jakarta, Indonesia \\ ¿Universitas Diponegoro, Semarang, Indonesia \\ Email: suryono.efendi@yahoo.com
}

\begin{abstract}
This study aims to determine the role and influence of the variables of intellectual capital, intrinsic motivation and Competence on the services of private university lecturers in Jakarta. This research uses quantitative research with a descriptive analysis approach. The population in this study were lecturers of the Faculty of Economics and the College of Economics at Kopertis Region III DKI Jakarta. The criteria for selecting the sample are: Lecturer of the Faculty of Economics and the College of Economics at Kopertis Region III DKI Jakarta, and the status of permanent lecturers of foundations and Seconded Lecturers (DPK) at Kopertis area III DKI Jakarta and at least have the academic position of Lector. The sample selection in this study used purposive sampling. The data collection method used in this research is structured interviews using a Personal Questionnaire. Primary and secondary data were analyzed in this study. The Validity Test, the Reliability Test, the Multiple Linear Regression Test, and Hypothesis Testing are used to analyze the data in this study (F Test and Partial Hypothesis Testing). The findings and analyses suggest that there is a positive and significant relationship between Intellectual Capital, Intrinsic Motivation, and Competence and the service performance of private university lecturers in Jakarta.
\end{abstract}

Keywords: Intellectual Capital, Intrinsic Motivation, Competence, Service, Lecturer.

\section{A. INTRODUCTION}

Typical and values universally accepted by the entire world community in the current era of globalization are deals that must be obeyed and cannot be negotiated (Abualoush, Masa'deh, 2018). The main requirement for creating a civil society is to accept and respect these universal values and norms (Andreeva \& Garanina, 2017). Apart from industry and business, this also happens in education on an extensive global scale (Bontis, Ciambotti \& Sgro, 2018). Globalization also poses challenges for universities in Indonesia due to the increasing competition between local universities and foreign universities. HRD, on a micro-scale, is marked by changes and shifts in the type of community, from an industrial society based on tangible resources to a scholarly organization based on science, technology and information (Efendi, 2021).

The increasingly diverse and information-based needs of society have a consequence for organizations to work harder with various strategies to meet these needs (Buenecha \& Kianto, 2018). The shift in technology from complex automation 
to intelligent technology controlled by society can be fulfilled to the fullest. Only knowledge workers can make innovative technology productive (Cabrita, da Silva \& Rodrigues, 2017). Knowledge workers have the knowledge, skills, and linear competencies; these skills are obtained from formal education and additional learning outside formal education. This is a challenge for education providers (Efendi, 2020).

Education providers are increasingly required to create graduates who are knowledgeable and have competent abilities (Cabrita \& Bontis, 2008). This is inextricably linked to the implementation and enhancement of numerous internal instruments. Additionally, the government has established Government Regulation No. 19 of 2005 about National Education Standards in order to minimize errors in this area. This rule intends to ensure the quality of national education through teaching citizens and molding the character and civilisation of a dignified nation.

Sangkala (2006) previously stated that human capital and structural capital have a positive and indirect effect on the effectiveness of advertising materials as corporate intellectuals through value creation and knowledge management in advertising companies in Jakarta. Likewise, research conducted by Ramirez (2007), this study concludes that the most critical resources of the university are educators (lecturers), researchers, administrative staff and students (human capital) with organizational processes (structural capital) and network of relationships (relationship capital). Higher education is a producer of knowledge. It consists of a knowledgeable community (intellectual capital) that can learn, the power of innovation, and an input processed through knowledge management.

In contrast to Bezhani's (2010) research, this study was undertaken at institutions in England. The findings of this study demonstrate that evaluating intellectual capital is still a relatively new practice in the United Kingdom. The low consequence of intellectual capital measurement at universities in Europe and Indonesia is one of the considerations for further research related to performance measures in terms of intangible assets (intellectual capital). Private college is one of the references to measure performance.

The proliferation of private institutions has heightened competitiveness in the realm of higher education. Universities as higher education management units are finally structured to function like modern mega-corporations that prioritize efficiency and effectiveness at all times. By the end of 2013, 336 higher education institutions were consisting of 127 academies (38\%), 53 universities (16\%), 13 institutes (4\%), 136 colleges (40\%), and seven polytechnics (2\%). Of the many universities, it turns out that the number of research and publications carried out by lecturers at Kopertis Region III DKI Jakarta for the period 2011-2013 is very minimal; this shows that the performance of lecturers has not been maximized. The number of research grants is 368, Fundamental Grants 78, PT Leading Grants amounted to 88, Workers amounted to 9 studies, post-graduate research amounted to 3 studies Doctoral Dissertations totalled 26 studies. Beginner research amounted to 84 pieces of this research. The data is undoubtedly a benchmark that the performance of 
lecturers needs to be improved again to achieve superior and competitive universities. When compared with the number of lecturers during 2011-2013, it was only $3 \%$. From the known data, the number of permanent lecturers based on the academic position of Teaching Staff is 10,179 or $47.1 \%$, permanent lecturers based on the theoretical status of Expert Assistant 4,391 or 20.3\%, permanent lecturers based on the academic position of Lector 4,807 or $22.2 \%$, permanent lecturers based on the educational level of Head Lector 1,876 or $8.69 \%$, while permanent lecturers based on the theoretical position of Professor 371 or $1.71 \%$. There are 21,624 permanent lecturers based on academic assignments.

Based on the data above, it shows that the performance of lecturers in the Kopertis Region III DKI Jakarta area in conducting research is deficient. Universities in the Kopertis Region III DKI Jakarta area face challenges in the quality of institutional governance, problems with the quality of human resources, and academic processes. Intellectual capital development can be used to achieve a competitive advantage in human resource development (HRD) practice (Xu \& Wang, 2018).

Human resource development dynamics are defined by the rise of employee diversity within a business or educational institution (Chen, Cheng \& Hwang, 2005). Diversity can be interpreted as differences in abilities or competencies between lecturers in an educational institution. So with this diversion, it is necessary to have a policy from the leadership of higher education institutions to develop the human resource sector (Efendi, 2021). Given the significant role of human resources in an organization, organizational management must be more proactive in making its human resources human capital that needs to be considered and developed continuously following the dynamics of the surrounding environment (Iqbal, Latif, Marimon \& Hussain, 2019). It can be seen that organizations that have good performance are also supported by human capital with high knowledge and skills. Organizations can use the knowledge possessed by HR as human capital to improve organizational performance where HR will continue to develop with the knowledge they have to adapt to the times.

\section{B. LITERATURE REVIEW}

\section{Intellectual Capital}

Intellectual capital is the sum of all things known and given by everyone in the company/organization, providing a competitive advantage (Khalique, Bontis, Shaari \& Ngah, 2018). Unlike the assets generally recognized by business entrepreneurs and accountants, namely land, plant, equipment, and cash, the nature of intellectual capital is intangible. Intellectual capital can also be interpreted as intelligent material (knowledge, information, intellectual property rights) that can create wealth (Kianto \& Aramburu, 2017). Included in intellectual capital is the workforce's ability, the intuition of a team of experts, or the workforce's expertise that produces a thousand alternatives to improve organizational capabilities. This can also be referred to as collective thinking power. In addition, Binker (2000) 
equates intellectual capital as the sum of human capital and structural capital (e.g. the relationship between lecturers and students in learning). Intellectual capital is significant for the development of education because it is an organizational virtual asset that can create value for an organization or university through a combination of human capital and Competence.

Intellectual Capital is one of the three types of critical intangible resources in the organization and the other two types, namely, (1) physical capital and (2) financial capital. According to Maar (2008), intellectual capital includes all intangible resources that can contribute to the implementation of organizational strategy and can be classified into three groups of resources, namely; (1) Human Capital, (2) Relational Capital and (3) Structural Capital (Li \& Liu, 2018).

In the context of higher education, human capital includes skills, experience possessed by lecturers, practical knowledge and implementation of strategies, success in the organization in the workplace, and attitudes as professionals in their respective fields (Liu, Kianto \& Tsui, 2020). Relational capital includes all existing relationships between organizations and other parties, for example, between lecturers and students, between lecturers and other lecturers and so on. In addition, organizational Structural Capital includes various types of vital factors for an organization. One of the most important factors is the primary operating process in the organization, such as organizational structure, policies, information flow, the content of data-based management style, corporate culture. Based on this, a hypothesis can be drawn as follows: H1: It is suspected that there is a positive and significant influence between Intellectual Capital on the service performance of private university lecturers in Jakarta.

\section{Intrinsic Motivation}

Intrinsic motivation can be interpreted as motives that can function without being stimulated from outside because there is already that drive within each individual. There are two types of variables that motivate an individual to seek satisfaction and disengage from dissatisfaction (Prahiawan \& Simbolon, 2014). The two components are referred to as hygiene factors (extrinsic factors) and motivational factors (intrinsic factors): a) Hygiene factors, which include human interactions, rewards, and environmental conditions, drive a person to overcome discontent (extrinsic factors); and b) Motivating variables, which include accomplishment, recognition or reward, the work itself, responsibility, and possibilities for progress, inspire a person to seek satisfaction (intrinsic factor) (Rastogi, 2000).

Ability and motivation are factors that interact with the performance. Skills and knowledge can determine a person's power, while skills can be influenced by skills (Sidharta \& Affandi, 2016). Personality and ability can be affected by education, training experience and interests. Motivation can be sourced from a person (intrinsic motivation) and can also be sourced from outside a person (extrinsic motivation). These motivational factors can positively or negatively impact 
a lecturer (Sriekaningsih \& Setyadi, 2015). In this case, a lecturer is required to have intrinsic work motivation to display adequate abilities and work results. Suppose the lecturer does not master the material to be taught and does not master the educational foundation, is unable to carry out the functions and duties as an educator and teacher, has low work motivation, lacks initiative and is less creative in organizing and writing teaching materials, less productive, less sociable in socializing and less informative. In that case, students tend not to be interested in attending lectures. Based on this, a hypothesis can be drawn as follows: H2: It is suspected that there is a positive and significant influence between motivation on the service performance of private university lecturers in Jakarta.

\section{Competence}

The components of individual Competence are divided into three parts, namely (a) intellectual Competence, (b) emotional Competence and (c) social Competence. Further stated, this intellectual Competence is internalized in the form of nine competencies, namely: (1) Achievement, (2) Job Security, (3) Initiative, (4) Mastery of Information, (5) Analytical Thinking, (6) Conceptual Thinking, Expertise Practical, (8) Linguistic Ability, and (9) Narrative Ability. Individual emotional Competence is internalized in the form of six levels of will and ability: (1). Sensitivity or mutual understanding, Concern for internal and external customer satisfaction; (3) Self-control, (4) Confidence, (5) Adaptability, and (6) Commitment to the organization. Individual social Competence is internalized in the form of seven levels of willingness and ability, namely: (1) Influence and Impact, (2) Organizational awareness, Building working relationships, (4) Developing others, namely the ability to improve the skills of subordinates or others by providing feedback which is constructive based on specific facts and provide training, (5) Directing subordinates, (6) Teamwork, (7) Group leadership.

In today's information-based education era, human resources will be a source of strength for organizations to achieve their goals if they have reliable competencies and are relevant to the demands of the work to be done (Sugiono, Hidayat \& Efendi, 2020). Therefore, organizational leaders must plan the development of lecturer competencies following job designs and business development plans both now and in the future based on the development of corporate development projections that have been stated in the long-term goals and strategies that have been chosen. Ideally, the development of individual competencies of lecturers should be carried out in a balanced manner between intellectual, social, and emotional competencies.

Spencer confirms that individual competence is a generally consistent characteristic of attitudes and behavior in dealing with a problem that is a synergy between one's self-concept, personality, internal motivation, and a lecturer's capability in his professional career (Sumardi \& Efendi, 2021). Individual competences are formed when the five sources or traits of competence interact and synergize. As one of the qualities of humans, knowledge and skill competencies are more obvious and relatively surface, making them slightly easier to build through 
experience or instruction. Meanwhile, character and motivational competences are typically more concealed, profound, and important to the lecturer's personality, making them somewhat difficult to analyze and develop. On this basis, the following hypothesis can be made: H3: It is assumed that there is a positive and significant relationship between Competence on the service performance of private university lecturers in Jakarta.

\section{METHOD}

This research uses quantitative research with a descriptive analysis approach. The population in this study were lecturers of the Faculty of Economics and the College of Economics at Kopertis Region III DKI Jakarta. The criteria for selecting the sample are: 1) Lecturer of the Faculty of Economics and the College of Economics at Kopertis Region III DKI Jakarta; and 2) The status of permanent lecturers of foundations and Seconded Lecturers (DPK) at Kopertis area III DKI Jakarta and at least have the academic position of Lector. The sample selection in this study used purposive sampling. The data collection method used in this research is structured interviews using a Personal Questionnaire. The data used in this study are primary data and secondary data. Data analysis in this research uses the Validity Test, Reliability Test, Multiple Linear Regression Test, and Hypothesis Testing (F Test and Partial Hypothesis Testing).

\section{RESULT AND DISCUSSION}

\section{Description of Research Respondents}

Demographic analysis was conducted based on the gender and age of the respondents. The age of the respondent can be used as a reference to assess the performance of lecturer services. Based on the aspect of Gender and Age, the composition of the research respondents was obtained as follows:

Table 1. Respondents by Gender and Age

\begin{tabular}{|c|c|c|c|}
\hline \multirow{2}{*}{ Age } & \multicolumn{2}{|c|}{ Gender } & \multirow{2}{*}{ Amount } \\
\cline { 2 - 3 } & Male & Female & \\
\hline $30-35$ years & $1(0.5 \%)$ & $4(1.8 \%)$ & $5(2.2 \%)$ \\
\hline $36-40$ years & $19(7.9 \%)$ & $12(5.0 \%)$ & $31(12.7 \%)$ \\
\hline $41-45$ years & $20(8.2 \%)$ & $15(6.1 \%)$ & $35(14.6 \%)$ \\
\hline $46-50$ years & $42(17.5 \%)$ & $28(11.7 \%)$ & $70(28.8 \%)$ \\
\hline$>50$ years & $56(23.0 \%)$ & $45(18.5 \%)$ & $101(41.7 \%)$ \\
\hline Amount & $138(57.0 \%)$ & $104(43.0 \%)$ & $242(100 \%)$ \\
\hline
\end{tabular}

Source: primary data processed

Based on table 1 above, it states that all 242 lecturer data are for the crosstabs process. From these results, the lecturers aged 30-35 years are one respondent with male gender and four respondents with the female gender. The percentage of respondents with male gender to the actual gender is $0.4 \%$, and the portion of the number of respondents with female gender to the existing gender is $1.7 \%$. 
Lecturers aged 36-40 years had several respondents with male gender and 19 respondents with 12 respondents with the female gender. The percentage of the number of respondents with male gender to the actual gender is $7.9 \%$, the percentage of the number of respondents with female gender to the total gender is $5 \%$. Lecturers are 41-45 years old, 20 respondents are male, 15 respondents are female lecturers. The percentage of the number of respondents with male gender to the actual gender is $8.3 \%$, the rate of the number of respondents with a female lector gender to the total gender is $6.2 \%$.

Lecturers aged 46-50 years are 42 respondents with male gender and 28 respondents with female head gender. The percentage of the number of respondents with male gender to the actual gender is $17.5 \%$, the percentage of the number of respondents with female gender to the total gender is $11.7 \%$. Lecturers aged $51-55$ years were 34 respondents with male gender and 15 respondents with the female gender. The percentage of the number of respondents with male gender to the actual gender is $14 \%$, the rate of the number of respondents with female gender to the total gender is $6.1 \%$.

Lecturers are aged 56-60 years, 19 respondents with male gender, 18 respondents with the female gender. The percentage of the number of respondents with male gender to the actual gender is $7.9 \%$, the percentage of the number of respondents with female gender to the total gender is $7.4 \%$. Lecturers with age $>60$ years are three respondents with male gender and 12 respondents with the female gender. The percentage of the number of respondents with male gender to the actual gender is $1.2 \%$, the portion of the number of respondents with female gender to the total gender is $5 \%$.

Given the significant role of human resources in an organization, the organization's management must be more proactive in making its human resources human capital that needs to be considered and developed continuously following the dynamics of the surrounding environment. It can be seen that organizations that have good performance are also supported by human capital with high knowledge and skills. Organizations can use the knowledge possessed by HR as human capital to improve organizational performance where HR will continue to develop with the knowledge they have to adapt to the times. This can be done dynamically and in a short time if the majority of lecturers are of productive and developing age (30-45 years). In this study, it was found that the majority of lecturers were more than 50 years old, so that service performance could be said to be less than optimal.

\section{Validity Test}

A validity test is performed to determine a questionnaire's validity or reliability. A questionnaire is deemed to be valid if the questions on it can provide information about the subject being measured. Table 2 shows the results of the

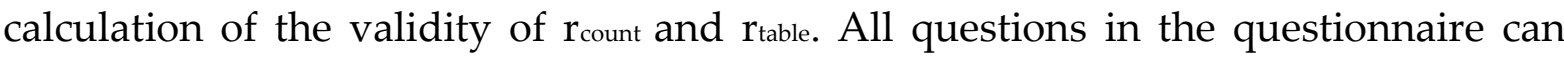
describe the actual situation. These questions can represent the situation that occurs 
in the field. The results of the validity test in this study are shown in the following table:

Table 2. Validity Test Results

\begin{tabular}{|c|c|c|c|c|}
\hline \multicolumn{2}{|l|}{ Indicator } & R-table & R-count & Information \\
\hline \multirow{5}{*}{ Intellectual Capital } & 1 & 0.482 & 0.8189 & Valid \\
\hline & 2 & 0.482 & 0.6161 & Valid \\
\hline & 3 & 0.482 & 0.6586 & Valid \\
\hline & 4 & 0.482 & 0.6578 & Valid \\
\hline & 5 & 0.482 & 0.6071 & Valid \\
\hline \multirow{5}{*}{ Intrinsic Motivation } & 1 & 0.482 & 0.6539 & Valid \\
\hline & 2 & 0.482 & 0.6539 & Valid \\
\hline & 3 & 0.482 & 0.6736 & Valid \\
\hline & 4 & 0.482 & 0.6629 & Valid \\
\hline & 5 & 0.482 & 0.7726 & Valid \\
\hline \multirow{5}{*}{ Competence } & 1 & 0.482 & 0.7621 & Valid \\
\hline & 2 & 0.482 & 0.6412 & Valid \\
\hline & 3 & 0.482 & 0.5613 & Valid \\
\hline & 4 & 0.482 & 0.5746 & Valid \\
\hline & 5 & 0.482 & 0.5702 & Valid \\
\hline \multirow{4}{*}{ Performance } & 1 & 0.482 & 0.6571 & Valid \\
\hline & 2 & 0.482 & 0.6458 & Valid \\
\hline & 3 & 0.482 & 0.6575 & Valid \\
\hline & 4 & 0.482 & 0.7541 & Valid \\
\hline
\end{tabular}

Source: processed data

From table 2 above, it can be seen that $r_{\text {count }}>r_{\text {table }}$ is based on a significant test of 0.05 . All variable values in the validity test were declared valid. This means that all questions in this study are considered reasonable and appropriate to measure the things measured in this study. This relates to the respondent's intellectual capital, divided into three things: a) Human Capital, b) Relational Capital and (3) Structural Capital. The question emphasizes how lecturers can become role models in classroom learning with students. Lecturer performance is also measured by how flexible a lecturer can communicate and organize with other lecturers in the existing organizational structure. This certainly affects the cohesiveness and can measure the Competence of lecturers both outside and inside the classroom.

\section{Reliability Test}

Reliability testing is carried out to ensure that the instrument used is a reliable, consistent, stable, and dependable instrument. The reliability coefficient, Cronbach's Alpha, was obtained in this study using SPSS. If the Cronbach's Alpha value is more than 0.6 , the questionnaire is considered credible. The reliability test results for this investigation are summarized in Table 3 below: 
Table 3. Research Reliability Test Results

\begin{tabular}{|c|c|}
\hline Variable & Cronbach's Alpha \\
\hline Intellectual Capital & 0.684 \\
\hline Intrinsic Motivation & 0.717 \\
\hline Competence & 0.715 \\
\hline Performance & 0.717 \\
\hline
\end{tabular}

Source: processed data

Table 3 shows the results of the reliability calculation for each questionnaire. The questionnaire used today is reliable and can be used many times. This means that the instrument used in the study can reveal essential information in the field; from the data, it can be seen that the tests in this study passed the degree of stability, consistency, predictive power and accuracy. The measurement results in this study have high reliability, and the resulting data is reliable.

\section{Multiple Linear Regression Test}

Multiple linear regression analysis was used to calculate the average estimated value and the value of the dependent variable (performance) in relation to the independent variables' values (Intellectual Capital, Intrinsic Motivation, and Competence). Multiple linear regression analysis was performed in this study using SPSS software. The reliability test results for this investigation are summarized in Table 4 below:

Table 4. Multiple Linear Regression Test Results

\begin{tabular}{|c|c|c|c|c|c|}
\hline \multirow{2}{*}{ Model } & \multicolumn{2}{|c|}{$\begin{array}{c}\text { Unstandardized } \\
\text { Coefficients }\end{array}$} & $\begin{array}{c}\text { Standardized } \\
\text { Coefficient }\end{array}$ & \multirow{2}{*}{$\mathrm{t}$} & Sig \\
\cline { 2 - 4 } & $\mathrm{B}$ & $\begin{array}{c}\text { Std. } \\
\text { Error }\end{array}$ & Beta & & \\
\hline (Constant) & 3.825 & 4.783 & & .800 & .431 \\
\hline Intellectual Capital & .926 & .135 & .767 & 6.928 & .000 \\
\hline Intrinsic Motivation & -.308 & .162 & -.213 & 1.1914 & .065 \\
\hline Competence & .922 & .127 & .728 & 6.917 & .055 \\
\hline
\end{tabular}

Source: processed data

Table 4 shows the results of SPSS processing for regression calculations in this study. From the results of the regression calculations above, the following equation is obtained: $\mathrm{Y}=3.825+0.926 \mathrm{X} 1+0.308 \mathrm{X} 2+0.922 \mathrm{X} 3$. This means, if all independent variables are 0 , then the value of the dependent variable is 3.825 . The coefficient value of X1 (Intellectual Capital) is 0.925 and is positive. The positive sign means that there is a unidirectional relationship between Intellectual Capital and performance. This unidirectional relationship implies that the higher the intellectual capital owned by the lecturer will positively affect the lecturer's performance at the university. This reflects the collective ability of lecturers to produce the best solutions based on the knowledge they already have to make the best solutions for various problems in the campus world in the information and technology era. 
Intellectual capital will increase if higher education institutions can maximize the knowledge possessed by lecturers, for example, through training programs, strict recruitment selection, mentoring, increasing individual potential and maximizing each lecturer's personality.

The coefficient value of X2 (Intrinsic Motivation) is 0.308 and is negative. The negative sign means that there is an opposite relationship between Intrinsic Motivation and performance. This opposite relationship implies that the Intrinsic Motivation of the lecturers does not have a positive impact on the performance of the lecturers in higher education. The intrinsic Motivation variable is measured by the indicators contained in Hezberg's (1966) theory, namely: a) Success; b) Recognition or award; c) The work itself; d) Responsibilities; and e) growth opportunities.

The coefficient value of X3 (Competency) is 0.922 and is negative. A positive sign means that there is a unidirectional relationship between Competence and performance. This unidirectional relationship implies that the higher the value of Competence possessed by the lecturer will positively affect the performance of lecturers in higher education. The organization's core competencies are organizing work and delivering value; Competencies can include communication, involvement, and an outstanding commitment to work across organizational boundaries. The performance of an organization reflects how effective the product/service is and how the organization can deliver it to customers. Human resources (HR) in the organization are tasked with designing, producing and providing through services. Therefore one of the targets of Human Resource Management (HRM) is to create activities that contribute to superior performance in higher education areas.

\section{Hypothesis Testing}

Statistical F-test was conducted to determine the effect of independent variables (Intellectual Capital, Intrinsic Motivation, and Competence) together on the dependent variable (service performance). The statistical $\mathrm{F}$ test in this study used SPSS software. The results of the research test in this study are presented in table 5 below:

Table 5. F Results of Research Statistics

\begin{tabular}{|c|c|c|c|c|c|}
\hline Model & $\begin{array}{c}\text { Sum of } \\
\text { Squares }\end{array}$ & df & $\begin{array}{c}\text { Mean } \\
\text { Square }\end{array}$ & F & Sig. \\
\hline Regression & 141.526 & 2 & 70.763 & 25.855 & .000 \\
\hline Residual & 82.112 & 30 & 2.738 & & \\
\hline Total & 223.637 & 32 & & & \\
\hline
\end{tabular}

a. Predictors: (Constant), Intellectual Capital, Intrinsic Motivation, Competence.

b. Dependent Variable: Service Performance

Table 5 shows that the resulting sig value is less than 0.05 , and $F_{\text {count }}>F_{\text {table, Ho }}$ is rejected, and Ha is accepted. Variables Intellectual Capital, Intrinsic Motivation, and Competence simultaneously have a significant influence on service performance. Performance is the result of work obtained by a person or group of 
people in an agency with their respective responsibilities in efforts to achieve agency goals following certain principles. From this, it can be checked whether the service performance of the lecturers in this study is following the Tri Dharma of Higher Education. In general, the Tri Dharma of Higher Education consists of 3 critical points: 1) Education and Teaching, 2) Research and Development, and 3) Community Service. In the first point, lecturers are required to provide the best results from the teaching carried out by lecturers and teaching staff following their intellectual abilities, motivations and competence abilities to produce excellent graduates; which will be able to be helpful as the next generation of the nation in a more advanced direction.

On the second point, research and development is also very important for a university lecturer, from research and development of science and technology, lecturers must be able to take advantage of this research and development in a learning process to obtain changes that are beneficial to society at large; This second point is a way to the third point, namely community service. Lecturers are required to be able to contribute and benefit the community based on their respective knowledge, therefore lecturers must know their respective portions according to their individual competencies.

\section{Partial Hypothesis Test}

It is necessary to test the significance by using a statistical test (t-test) using a significance level of 5\% (0.05) and degrees of freedom (DK) correlation with the formula: $\mathrm{DK}=\mathrm{nk}-1$, where $\mathrm{n}$ is the number of respondents, and $\mathrm{k}$ is the number of respondents. The variables studied.

\section{Intellectual Capital Variable}

The hypothesis in the Intellectual Capital variable is as follows:

Ha1: It is suspected that there is a positive and significant influence between Intellectual Capital on the service performance of private university lecturers in Jakarta.

Ho1: It is suspected that there is no positive and significant influence between Intellectual Capital on the service performance of private university lecturers in Jakarta.

Table 6. Hypothesis Test H1

\begin{tabular}{|c|c|c|c|c|c|c|}
\hline & \multirow[t]{2}{*}{ Model } & \multicolumn{2}{|c|}{$\begin{array}{c}\text { Unstandardized } \\
\text { Coefficients }\end{array}$} & $\begin{array}{l}\text { Standardized } \\
\text { Coefficients }\end{array}$ & \multirow[t]{2}{*}{$\mathrm{t}$} & \multirow[t]{2}{*}{ Sig. } \\
\hline & & $\mathrm{B}$ & Std. Error & Beta & & \\
\hline 1 & (Constant) & 5.854 & 2.050 & \multirow[t]{2}{*}{.735} & 2.856 & ,006 \\
\hline \multicolumn{2}{|c|}{ Intellectual Capital (X1) } & .514 & .047 & & 11.324 & .004 \\
\hline
\end{tabular}

a. Dependent variable: Service Performance (Y)

Source: Data processed 
Based on the table, it can be seen that the Intellectual Capital variable obtained a significance value of $t$ less than 0.05 or $0.003<0.05$ and $t$ count $11.324>t$ table 1.98, then H01 is rejected, and Ha1 is accepted, this shows that there is a significant effect Positive and significant impact of Intellectual Capital on the service performance of private university lecturers in Jakarta.

This is following research conducted by Joeliaty (2017) which found that intellectual capital has a positive and significant effect on the achievement of competitive advantage in undergraduate study programs at State Universities in Bandung. The essential aspect in determining competitive advantage is the nonsubstitutable and rare dimension, namely human resources (leaders, lecturers, and administrative staff) who have a high level of self-control, empathy and talent in serving students, and rare competencies to find in carrying out their duties. Meanwhile, what is still minor superior is the valuable and inimitable dimensions, namely human resources, especially the administrative staff who have not thoroughly carried out their duties effectively and have not shown their creativity in serving students.

This is also supported by research conducted by Christa (2018), which finds that the intellectual capital dimension positively affects the performance of higher education services in Central Kalimantan. Service performance from the results also proves that by increasing the feeling of self-esteem of lecturers with responsiveness, responsibility, speed and accuracy, and service accuracy will be very well driven by the intellectual capital dimension. One way that can be done is to recognize the needs of lecturers immediately, not to teach/teach lecturers, serve sincerely, provide opportunities for students to give suggestions and criticisms, and provide awards to students who are willing to take the time and are enthusiastic about spending time in learning.

\section{Intrinsic Motivation Variable}

The hypothesis in the Intrinsic Motivation variable is as follows:

Ha2: It is suspected that there is a positive and significant influence between Intrinsic Motivation on the service performance of private university lecturers in Jakarta.

Ho2: It is suspected that there is no positive and significant influence between Intrinsic Motivation on the service performance of private university lecturers in Jakarta.

Table 7. H2. Hypothesis Testing

\begin{tabular}{|c|c|c|c|c|c|c|}
\hline & \multirow{2}{*}{ Model } & \multicolumn{2}{|c|}{$\begin{array}{c}\text { Unstandardized } \\
\text { Coefficients }\end{array}$} & $\begin{array}{c}\text { Standardized } \\
\text { Coefficients }\end{array}$ & \multirow{2}{*}{$\mathrm{t}$} & \multirow{2}{*}{ Sig. } \\
\hline & & B & Std. Error & Beta & & \\
\hline 1 & (Constant) & 39.231 & 3.958 & \multirow{2}{*}{.128} & 9.908 & .000 \\
\hline \multicolumn{2}{|c|}{ Intrinsic Motivation (X2) } & .139 & .102 & & 2.368 & .005 \\
\hline
\end{tabular}

a. Dependent variable: Service Performance $(Y)$

Source: Data processed 
Based on the table, it can be seen that the motivational variable obtained a significance value of $t$ less than 0.05 or $0.004<0.05$ and $t$ count $2.368>t$ table 1.98 , then $\mathrm{H} 02$ is rejected, and Ha2 is accepted, this shows that there is a positive influence and the significance of intrinsic motivation on service performance.

The results of this study are corroborated by research conducted by Prahiawan (2014), who found that there was a significant influence between intrinsic motivation and work environment on employee performance at Intimas Lestari Nusantara Inc. Furthermore, Prahiawan said that there is a substantial influence between intrinsic motivation and work environment on employee performance with a coefficient of determination (KD) of $71 \%$, this shows that with good intrinsic motivation and supported by a safe and safe work environment. Comfortable for employees, it can improve employee performance (Prahiawan \& Simbolon, 2014).

However, it is different from the research conducted by Abbas (2013), which found that there was no influence between Intrinsic Motivation on teacher performance in the city of Ternate. Based on the data obtained by the researcher, it can be said that there are complex problems concerning the implementation of junior high school teachers in the city of North Ternate. Skills and knowledge can determine a person's ability, while skills can be influenced by skills (Abbas, 2013). Personality and knowledge can be affected by education, training experience and interests. Motivation can be sourced from a person (intrinsic motivation) and can also be sourced from outside a person (extrinsic motivation). These motivational factors can have a positive or negative impact on a teacher. In this case, a teacher must have the intrinsic motivation of the teacher's work, the extrinsic motivation of the teacher's work, and adequate Competence to display proper abilities and work results.

\section{Competency Variables}

The hypothesis in the Competency variable is as follows:

Ha3: It is suspected that there is a positive and significant influence between competence on the service performance of private university lecturers in Jakarta. Ho3: It is suspected that there is no positive and significant influence between competence on the service performance of private university lecturers in Jakarta.

Table 8. H3 Hypothesis Testing

\begin{tabular}{|c|c|c|c|c|c|c|}
\hline \multirow{2}{*}{\multicolumn{2}{|c|}{ Model }} & \multicolumn{2}{|c|}{$\begin{array}{c}\text { Unstandardized } \\
\text { Coefficients }\end{array}$} & $\begin{array}{c}\text { Standardized } \\
\text { Coefficients }\end{array}$ & \multirow{2}{*}{$\mathrm{t}$} & \multirow{2}{*}{ Sig. } \\
\hline & & $\mathrm{B}$ & Std. Error & Beta & & \\
\hline 1 & (Constant) & 29.813 & 4.269 & \multirow{2}{*}{.316} & 6.984 & ,000 \\
\hline & Competence (X3) & .387 & .112 & & 3.478 & .001 \\
\hline
\end{tabular}

a. Dependent variable: Service Performance (Y)

Source: Data processed

Based on the table, it can be seen that the work discipline variable obtained a significance value of $t$ less than 0.05 or $0.001<0.05$ and $t$ count $3,478>t$ table 1.98 , then $\mathrm{H} 03$ is rejected, and Ha3 is accepted, this shows that there is a significant effect. 
Positive and importance of the competence variable on the performance of educators.

The findings of this study are verified by Marliana Budhiningtias Winarti's (2011) research, which indicates that competence has an effect on employee performance (a survey at Frisian Flag Indonesia Inc. in the West Java region). When it comes to performance measurement, the most important issue is establishing the criteria. Job criteria are the most critical determinants of what individuals perform in their work. Job requirements, in a sense, define the work that the business has compensated its employees to perform. As a result, these factors are critical. Individual work performance must be quantified and compared to established standards, with the findings given to each employee (Buddhiningtyas, 2011).

Furthermore, the behaviour that shows the condition of lecturer competence does not meet the expectations of society and universities, for example: less fast in solving problems, less innovative in providing services because they are always waiting for orders from superiors, there are still many complaints from students about the lack of responsiveness of lecturers at the time of learning, do not understand work standards. The excellent news is that the information from the field has not been responded to well by the lecturer who has been given the task.

\section{E. CONCLUSION}

Based on the results and analysis conducted, it can be concluded that: 1) There is a positive and significant influence between Intellectual Capital on the service performance of private university lecturers in Jakarta; 2) There is a positive and significant influence between Intrinsic Motivation on the service performance of private university lecturers in Jakarta; 3) There is a positive and significant influence between Competence on the service performance of private university lecturers in Jakarta.

\section{REFERENCES}

1. Abbas, Y. (2013). Motivasi Intrinsik, Motivasi Ekstrinsik, Kompetensi dan Kinerja Guru. Humanitas: Jurnal Psikologi Indonesia, 10(1), 61-74.

2. Abualoush, S., Masa'deh, R., Bataineh, K., \& Alrowwad, A. (2018). The knowledge management process and intellectual capital are intermediary variables between knowledge management infrastructure and organization performance. Interdisciplinary Journal of Information, Knowledge, and Management, 13, 279-309.

3. Andreeva, T., \& Garanina, T. (2017). Intellectual capital and its impact on the financial performance of Russian manufacturing companies. Форсайm, 11(1).

4. Bontis, N., Ciambotti, M., Palazzi, F., \& Sgro, F. (2018). Intellectual capital and financial performance in cooperative social enterprises. Journal of Intellectual Capital. 
5. Budhiningtias Winanti, M. (2011). Pengaruh Kompetensi Terhadap Kinerja Karyawan (Survei pada PT. Frisian Flag Indonesia Wilayah Jawa Barat). Majalah Ilmiah UNIKOM.

6. Buenechea-Elberdin, M., Sáenz, J., \& Kianto, A. (2018). Knowledge management strategies, intellectual capital, and innovation performance: a comparison between high-and low-tech firms. Journal of Knowledge Management.

7. Cabrita, M. D. R. M. F., da Silva, M. D. L. R., Rodrigues, A. M. G., \& Dueñas, M. D. P. M. (2017). Competitiveness and disclosure of intellectual capital: empirical research in Portuguese banks. Journal of Intellectual Capital.

8. Cabrita, M. D. R., \& Bontis, N. (2008). Intellectual capital and business performance in the Portuguese banking industry. International Journal of Technology Management, 43(1-3), 212-237.

9. Chen, M. C., Cheng, S. J., \& Hwang, Y. (2005). An empirical investigation of the relationship between intellectual capital and firms' market value and financial performance. Journal of intellectual capital.

10. Efendi, S. (2020). The Role of Human Capital in the Education Sector in Efforts to Create Reliable Organizational Human Resources. International Journal of Science and Society, 2(1), 405-413.

11. Efendi, S. (2021). Lecturer's Pedagogic Competence in Developing Student Learning at the National University. Jurnal Mantik, 5(2), 701-706.

12. Efendi, S. (2021). The Role of Knowledge-Based Signature Skill (Specific Knowledge-Based Professional Ability) as a Mediation Variable in Intellectual Capital, Intrinsic Motivation, Empowerment of Creativity on Performance: (Empirical Study at Private Universities DKI Jakarta). Italienisch, 11(2), 321-334.

13. Efendi, S. (2021, June). Implementation of Talent Management as an Effort to Improve Employee Performance. In 2nd Annual Conference on blended learning, educational technology and Innovation (ACBLETI 2020) (pp. 537-542). Atlantis Press.

14. Efendi, S., \& Winenriandhika, O. (2021). Pengaruh Rekrutmen, Pelatihan dan Pengalaman Kerja Terhadap Kepuasan Kerja dan Dampaknya pada Kinerja Karyawan di PT. Marketama Indah. Akselerasi: Jurnal Ilmiah Nasional, 3(1), 99110.

15. Iqbal, A., Latif, F., Marimon, F., Sahibzada, U. F., \& Hussain, S. (2019). Knowledge management to organizational performance: Modelling the mediating role of innovation and intellectual capital in higher education. Journal of Enterprise Information Management.

16. Khalique, M., Bontis, N., Shaari, J. A. N. B., Yaacob, M. R., \& Ngah, R. (2018). Intellectual capital and organizational performance in Malaysian knowledgeintensive SMEs. International Journal of Learning and Intellectual Capital, 15(1), 2036.

17. Kianto, A., Sáenz, J., \& Aramburu, N. (2017). Knowledge-based human resource management practices, intellectual capital and innovation. Journal of Business Research, 81, 11-20. 
18. Li, Y. Q., \& Liu, C. H. S. (2018). The role of problem identification and intellectual capital in the management of hotels' competitive advantage-an integrated framework. International Journal of Hospitality Management, 75, 160170.

19. Li, Y., Song, Y., Wang, J., \& Li, C. (2019). Intellectual capital, knowledge sharing, and innovation performance: Evidence from the Chinese construction industry. Sustainability, 11(9), 2713.

20. Liu, G., Kianto, A., \& Tsui, E. (2020). A comprehensive analysis of the importance of intellectual capital elements to support contemporary developments in Chinese firms. In Intellectual Capital in the Digital Economy (pp. 62-73). Routledge.

21. Prahiawan, W., \& Simbolon, N. (2014). Pengaruh Motivasi Intrinsik dan Lingkungan Kerja terhadap Kinerja Karyawan pada PT Intimas Lestari Nusantara. Jurnal Ekonomi Universitas Esa Unggul, 5(1), 17914.

22. Rastogi, P. N. (2000). Knowledge management and intellectual capital-the new virtuous reality of competitiveness. Human systems management, 19(1), 39-48.

23. Sidharta, I., \& Affandi, A. (2016). The empirical study on the intellectual capital approach toward financial performance on rural banking sectors in Indonesia. International Journal of Economics and Financial Issues, 6(3).

24. Sriekaningsih, A., \& Setyadi, D. (2015). Competence, motivation, and cultural organization impact organizational commitment and performance on state university lecturers in East Kalimantan Indonesia. European Journal of Business and Management, 7(17), 208-220.

25. Sugiono, E., Hidayat, D. O., \& Efendi, S. (2020). Pengaruh Iklim Organisasi, Pelatihan dan Kompensasi Terhadap Kepuasan Kerja dan Dampaknya Terhadap Kinerja Pegawai Yayasan Mantab Al Hamid. Jurnal Ilmiah MEA (Manajemen, Ekonomi, \& Akuntansi), 4(2), 602-627.

26. Sumardi, R., \& Efendi, S. (2021). Upaya Meningkatkan Kinerja Dengan Pendekatan Aplikasi Balance Scorecard pada Perguruan Tinggi Swasta di Jakarta. Jurnal Sosial dan Humaniora, 4(8), 229-242.

27. Xu, J., \& Wang, B. (2018). Intellectual capital, financial performance and companies' sustainable growth: Evidence from the Korean manufacturing industry. Sustainability, 10(12), 4651. 